\title{
Non invasive palliation for advanced pancreatic cancer using high intensity focused ultrasound
}

\author{
Michele Rossi, Riccardo Naspetti, Ernesto Mazza, Paolo Boninsegni \\ From 2nd European Symposium on Focused Ultrasound Therapy \\ Rome, Italy. 10-11 October 2013
}

\begin{abstract}
Background
A majority of patients (85-90\%) diagnosed with pancreatic cancer has advanced disease at the time of diagnosis with a dismal prognosis. Pain is a common symptom in patients $(60-90 \%)$ with advanced disease. Pain is neuropathic and inflammatory, resulting from both tumour expansion and tumour invasion of the celiac and mesenteric plexus. Opioids have side effects and may not be sufficient while celiac plexus neurolysis is an invasive procedure, despite the questionable results reported. Currently, HIFU (high intensity focused ultrasound) an emerging procedure completely no invasive, has been gaining wide acceptance not only for treating neoplasm but for symptom's relief also.
\end{abstract}

\section{Materials and methods}

A 76 year old lady was referred to us with an advanced head-body adenocarcinoma of the pancreas with vascular encasement of the superior mesenteric artery and vein. She was jaundiced (bilirubin of $16 \mathrm{mg} / \mathrm{dL}$ ) and complained of back pain consistent with tumor-related pain with a visual analogue scale (VAS) of $9 / 10$ and daily opioids assumption. Endoscopic placement of a metal stent followed by HIFU treatment was considered the best suitable option.

\section{Results}

A single step HIFU procedure was performed after an endoscopic retrograde cholangiopancreatography (ERCP) and biliary metallic stenting. Total treatment time was $1 \mathrm{~h}$ and $50 \mathrm{~min}$, with a sonication time of $60 \mathrm{~min}$. Treatment power used ranged between 400 and $150 \mathrm{~W}$, although mainly higher intensity energies were used. Total ablated volume was $80 \%$. No complications occurred and total hospitalization lasted one day. Amylase and bilirubin level

\footnotetext{
Azienda Ospedaliero universitaria Careggi - Firenze, Italy
}

Submit your next manuscript to BioMed Central and take full advantage of:

- Convenient online submission

- Thorough peer review

- No space constraints or color figure charges

- Immediate publication on acceptance

- Inclusion in PubMed, CAS, Scopus and Google Scholar

- Research which is freely available for redistribution 